\title{
The precautionary principle and biological invasion: the case of the House Sparrow on the Lesser Antilles
}

\author{
(Keywords: decision-making process, eradication, exotic bird, multi-spatial scales, multi-actor guide, Passer domesticus)
}

\author{
PHILIPPE CLERGEAU†*, ANTHONY LEVESQUE $\$$ and OLIVIER LORVELEC $\dagger$
}

$\dagger$ Institut National de la Recherche Agronomique, SCRIBE, Avenue du Général Leclerc, 35042 Rennes cedex, France ¥AMAZONA, Bois de Bragelogne, 97118 Saint François, Guadeloupe, France

\begin{abstract}
The capacity to react quickly to species introductions and to plan effective management countermeasures is always difficult, and methodology is lacking. This paper summarizes the different steps of a decision-making protocol applied to the recent establishment of an exotic species, the House Sparrow Passer domesticus, in the Lesser Antilles. This pest bird damages crops, fruits and stored food products and also competes with numerous hole-nesting birds in a large part of its range, and this requires more or less rapid management decision to limit its impact. In order to construct a base for decision-making in the Lesser Antilles case, we designed and conducted a brief biological study involving three spatial scales. At the regional scale, we defined the state of spread of House Sparrows throughout the West Indies. At the island scale, we estimated the number and distribution of breeding colonies. At the local scale, we estimated the numbers and behaviour of House Sparrows. To enable a quick decision to be made, we also suggested organizing a collective decision-making process applying a multi-actor guideline taking account of the different kinds of actors and levels of competence. We applied this method and we presented our results to a multi-actor workshop. The collective decision-making chose to apply the precautionary principle on one island (bird eradication) and to install both communications and monitoring plans. The procedure involving both multi-spatial scale assessment and a multi-actor workshop needs to be refined but its prospects are promising.
\end{abstract}

\section{Introduction}

Recently, the impact of introduced species has clearly been shown to be one of the most important threats to biodiversity and species conservation (Soulé, 1990), and also to agricultural and fisheries production (Mack et al. 2000). Throughout the world there have been enormous numbers of introductions of plant and animal species since the last part of the 19th century. Intentional and unintentional releases of alien species are still continuing in numerous countries and especially on islands.

The capacity to react to species introductions and to plan effective management countermeasures is affected by the great speed of dispersal of many introduced species. The faster the colonization process, the faster human intervention such as site protection or eradication must be. When the introduced species is abundant and well established, difficulties increase, and, in many cases, population increase and dispersal speed prevents the use of conventional methods of intervention (Feare, 1991, Clergeau, 1997). We now know enough about problems linked to invasions to avoid repeating earlier mistakes (Johnston and Garret, 1994, Williamson, 1996, Clergeau and Mandon-Dalger,
2001). Authorities have to be able to decide very quickly if control measures against an invader have to be conducted, even if the impact of this species on the new locality cannot be assumed to be important. This is the definition of the 'precautionary principle' that has been applied to several problems in ecology, sociology and economics when presumptions of damage risks exist (O'Riordan and Cameron, 1994, Rogers et al., 1997, Godard, 1997). The Principle requires action to prevent damage even before harm can be scientifically demonstrated or economically assessed; application can be based on economic risk simulation (Rogers et al., 1997) but also on ecological assessment when the context of precaution has yet to be clearly defined, such as in biological invasion management (IUCN, 2000). However, especially in France, a methodology for fast decision-making processes often seems lacking when a new pest is detected.

An example of this appeared recently in the French West Indies when the House Sparrow was first observed on two islands in 1999. This bird is known to damage grain, especially sorghum, maize, and wheat, in fields, poultry rations, storage sheds or livestock feedlots; disbudding of fruit trees and sprouting vegetables and flowers is also common in numerous parts of its current range (e.g. in Oceania: Dawson, 1970; in Europe: Rekasi, 1976; in Africa: Ghabour, 1972 and in the USA: Royall, 1969, see also review in Summers-Smith, 1988, Pinowski and Summers-Smith, 1990). The current significant threats linked to the House Sparrow in America are today not only the agricultural losses cited in literature, but also the displacement of native species of birds. The House Sparrow competes for nesting sites with native cavity-nesting birds and its aggressive flocks also discourage other birds from foraging in the same area (Bryant, 2002; Kern, 2003).

Making a decision on whether to act on the establishment of this passerine has not always been easy because the numerical and spatial status of its colonization was unknown and because many people were unwilling to accept the killing of a 'friendly' bird without clear justification (Conover, 1997, Reiter et al., 1999). To improve the rapidity of decision-making by the authorities, we proposed testing together two methodologies. First, we used a multi-spatial scale methodology, including mapping, that appeared to be a good tool for wildlife diagnosis and for communication (Clergeau, 1995, Clergeau et al., 2002). Accordingly, in February-March 2002 we conducted a study of the

*To whom correspondence should be addressed. INRA-SCRIBE, avenue du Général Leclerc, 35042 Rennes cedex, France. 
House Sparrow distribution on the French West Indies at three spatial scales. Secondly, it was suggested that the various stakeholders became involved in a collective decision-making process as soon as possible, that would allow quick and socially acceptable solutions to be found and would solve the management of conflicts among stakeholders with opposing viewpoints (Norton et al., 1999, Le Lay et al., 2001, Clergeau et al., 2002, Chase et al., 2002). This paper summarizes the different steps of this decision-making process.

\section{The case of House Sparrow}

The House Sparrow Passer domesticus, which originated from the Palearctic zone, is probably the most cosmopolitan invasive bird species throughout the world. It was first introduced into the USA in 1850 and rapidly invaded a large part of North America including southern Canada and most of Mexico (Sibley, 2000). Today it is also present in South America, presumably introduced directly from the Old World (Ridgely and Greenfield, 2001), from western Colombia to Chile and from eastern Brazil to Paraguay and Argentina (AOU, 1998). Recently it has been expanding its range rapidly in Central America (Fleischer, 1982).

In the West Indies, the House Sparrow first appeared in Cuba in 1865 and next in Jamaica in 1903 and on Grand Bahama and New Providence Islands in the Bahamas shortly thereafter. More recently it appeared on Saint Thomas in the American Virgin Islands in the early 1950s, on Hispaniola (1976)and Puerto Rico (1978) (Raffaele et al., 1998, see also reference review in Wiley, 2000). The Greater Antilles is geographically separated from the Lesser Antilles by the Anegada Strait. As a consequence, in the 1990s, although the House Sparrow was common in the majority of the Greater Antilles, it had not yet established on the Lesser Antilles. Some observations in 1999 and 2000 of several House Sparrows on French West Indian islands, Saint-Martin and Guadeloupe, suggested a recent expansion within the Lesser Antilles (Levesque and Clergeau, 2002). The 'Direction Régionale de l'Environnement' of Guadeloupe, the official environmental authority of the French West Indies, wanted to make a quick decision on what management should be applied to this bird invasion, especially in the context of the new projects on tropical biodiversity in 'ultra peripheral European regions' (art. 169 of Sixth European Framework Programme).

\section{Methods}

\subsection{Multi-spatial scale methodology}

Our main goal in this study was to evaluate the risk of propagation of House Sparrows. To examine relationships between new colonies and the distance from installed populations, we focused on the location of the different breeding colonies and the number of House Sparrows. We used a multiscale approach to construct various maps to help in decisionmaking. At a large regional scale, we assessed the distribution of the House Sparrow in the West Indies and the distance of islands from the species source. At an island scale, we assessed the number of breeding colonies on recently invaded islands. At the local scale, we assessed the number of birds within each colony and the main behaviour, such as the main roosting and feeding sites.
To assess the distribution of the House Sparrow at the regional scale we: (i) reviewed studies on West Indian birds, using especially the review of Wiley (2000) and we obtained 11 publications that reported the dates of first occurrence of House Sparrows on the various islands of the Greater Antilles; (ii) contacted ornithological associations of the different countries in the West Indies to obtain data on the recent status of the House Sparrow's distribution. The results were translated into a map representing the spread of the House Sparrow through the West Indies and the quality of recent observations (no observation, only one individual, several individuals with nests).

At the island scale, we focused on the recently invaded French islands of Saint-Martin and Guadeloupe, where breeding has already been reported. We determined the distribution of the species within these islands using census on a grid system. We divided each island into $5 \mathrm{~km}$ squares: 55 squares for Guadeloupe and six squares for Saint-Martin, including the Dutch part. In each square, we selected three points of favourable habitat (village, town suburb, chicken farm, etc.) and at each point we performed 10 min point counts for House Sparrows. In 11 squares in Northern Guadeloupe, the more favourable sector for House Sparrow, we increased the number of observation points to one point per kilometre. A total of 249 point counts were made on Guadeloupe. In April 2002, we also placed an advertisement in daily newspapers asking for people to report locations of the sparrows on Guadeloupe and Saint-Martin. The participation of birdwatchers and also the general public clearly appears to be an important point of methodology in obtaining fast results.

At the local scale, we focused on the colonies recorded by grid census or by human contacts following the press call. We tried to estimate the number of House Sparrows, the number of nests, the main roosting site and its characteristics, if a principal feeding site existed and if there were other small colonies near the main colony. To obtain these data, two observers worked simultaneously on each colony for at least 2 days.

\subsection{Multi-actor methodology}

In a majority of cases, scientific experts now have to help in decision-making processes involving wildlife management of species such as pest birds for which there are no consensual judgments in human activity contexts. Although no single strategy can be applied in all situations (Chase et al., 2002), we can develop guidelines adaptable to each human-wildlife context. From previous studies (Clergeau, 1995, Monachesi and Albaladejo, 1997, Le Lay et al., 2001, Clergeau et al., 2002), we had developed a guide that involves all the potential actors (experts, affected populations, local and central government authorities, government executive organizations) and also the different levels of organization (figure 1A). In each case, categories of actors and categories of levels have been analysed according to the context and the species to manage.

For this House Sparrow problem, we applied our 'multi-actor guide' that suggested the organization of a workshop with the most complete panel of different 'actors' taking account of the different levels of competence. This kind of decision-making is not common concerning alien invasive species and it is the first such experience for the French West Indian authorities.

We presented our result maps to the actors and suggested several scenarios for intervention. These were the basis of 

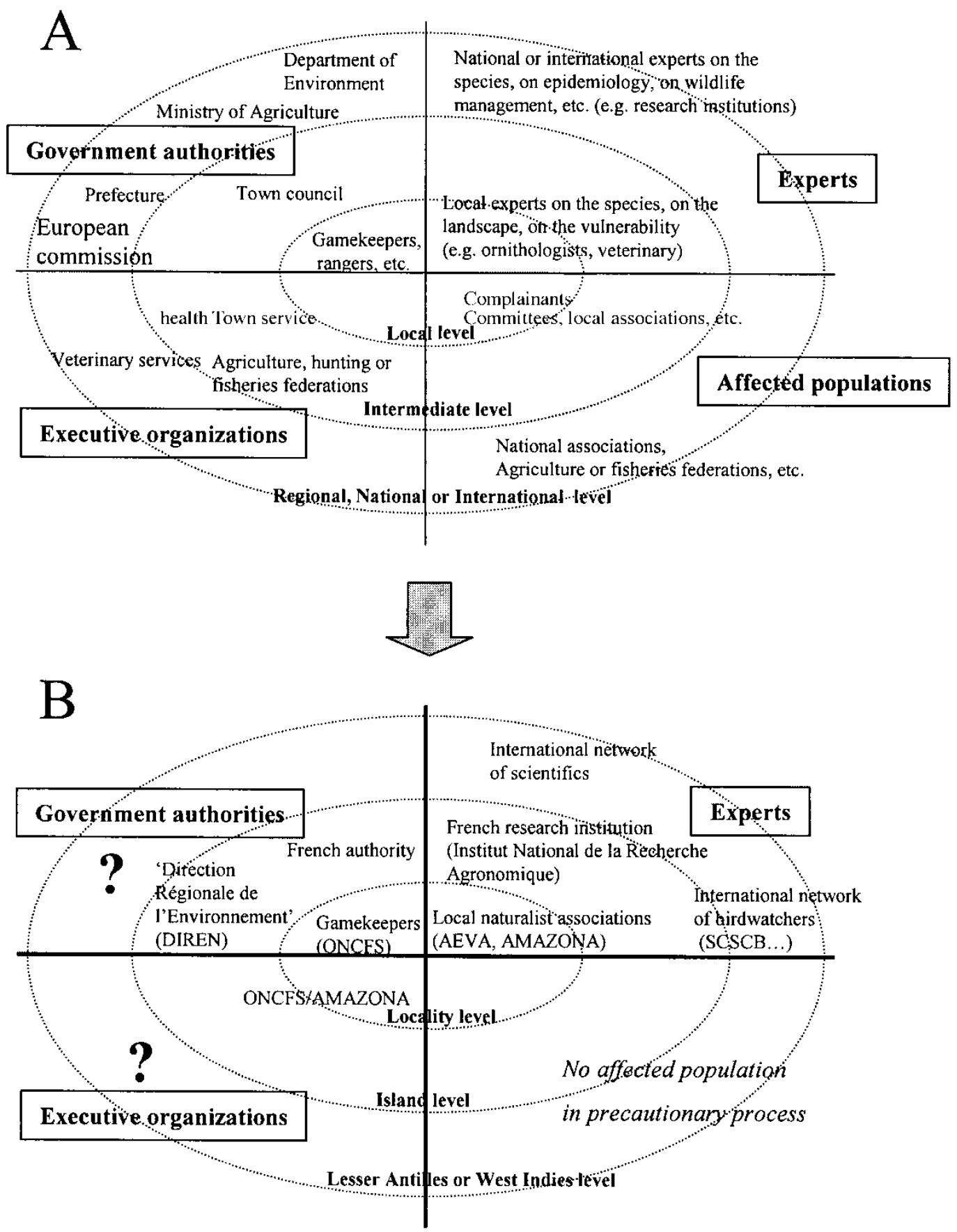

Figure 1. Network of actors required for collective decision-making on wildlife assessment and management. A: The general 'multi-actors' guideline integrating four kinds of actors at several levels of organization or competence; some examples of urban and agricultural system 'actors' are given (modified from Clergeau et al., 2002). B: actor network involved in making decision about House Sparrows in the French West Indies.

collective negotiation that must converge on a consensual management decision.

\section{Results and discussion}

\subsection{Biological data}

At the Regional scale, we have confirmed the distribution of the House Sparrow throughout the Greater Antilles. At the extreme east, Raffaele et al. (1998) noted it on Saint John (Virgin Islands), Saint Thomas (American Virgin Islands) but not on Anegada (British Virgin Islands), the nearest island to the Lesser
Antilles. The approximate limit of the House Sparrow's distribution in the 1990s is shown in figure 2. The first published records of the House Sparrow in the Lesser Antilles were by Levesque $(1999,2001)$ who observed a few bird families on Saint-Martin and Guadeloupe. Our requests to ornithologists confirmed the establishment (several nests) on Saint Croix (American Virgin Islands) (Trimm, 1999, Hayes, 2002, personal communications) in the Greater Antilles, but no other establishment on the Lesser Antilles. However, only one observation without confirmed breeding was reported on Barbuda in 1989 (Mussington, 2002, personal communication), on Barbados in 1997 (Frost, 2002, personal communication), Saint Lucia in 1999 (Keith, 2002, 


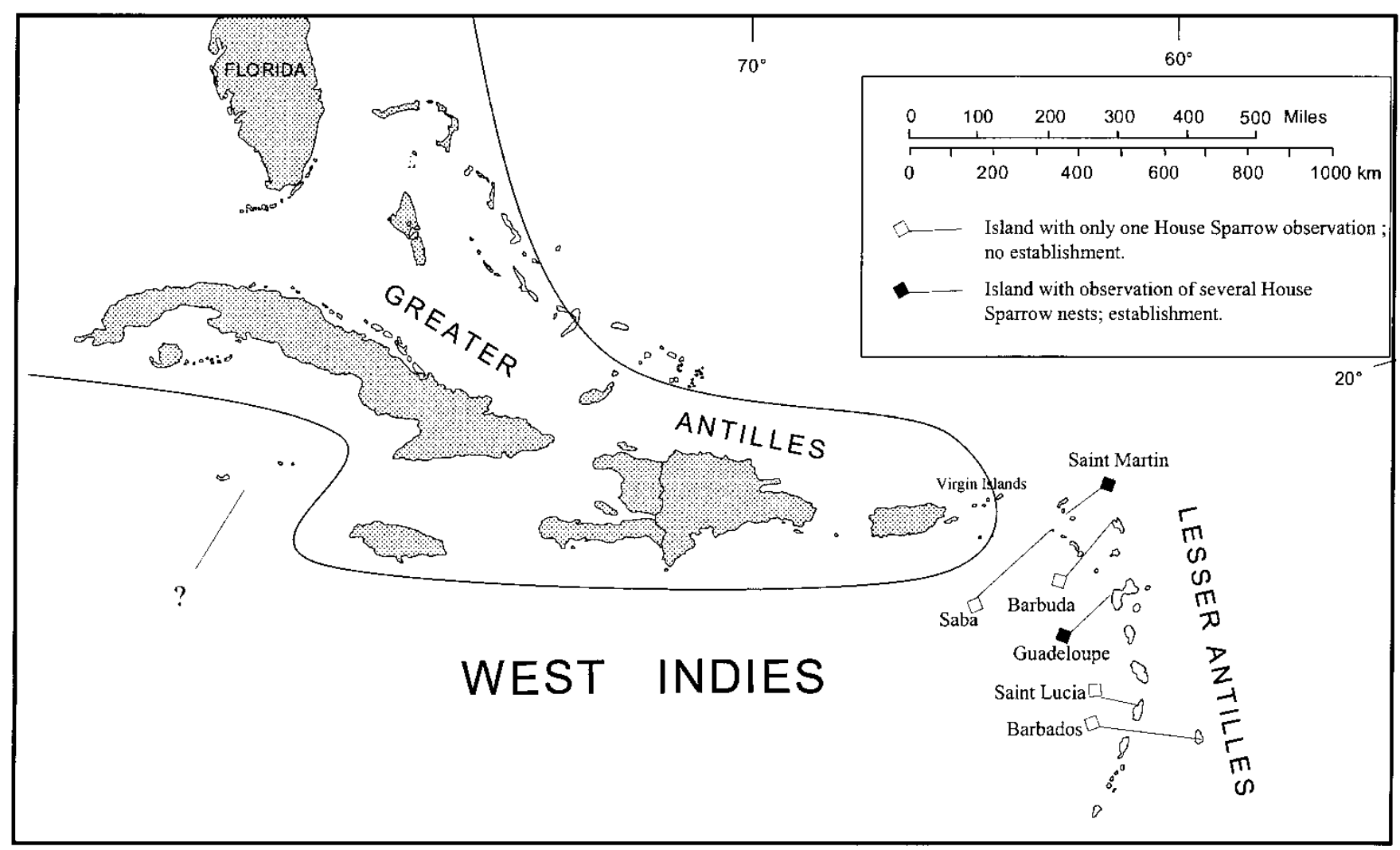

Figure 2. Map of the West Indies, first, with the approximate distribution limit of House Sparrow in the 1990s, including most of the Greater Antilles and Florida, and, second, recent observations of this bird in the Lesser Antilles since 1995. ? = no data.

personal communication), and Saba in 2001 (Walsh-McGehee, 2002, personal communication). House Sparrows have never been reported on the other islands of the Lesser Antilles (figure 2). Saint-Martin and Guadeloupe are located respectively at more than 200 and $400 \mathrm{~km}$ from the Virgin Islands.

At Island scale, the results of 10 min-census gave 3 points with House Sparrows on Saint-Martin (respectively 25 and 6 birds at Cul-de-Sac village and 1 at Grand-Case village) and 2 on Guadeloupe ( 1 and 7 birds at Campêche village). Responses to our newspaper request calls produced 3 more points: 2 on SaintMartin (at Marigot and Mullet Bay villages) and 1 on Guadeloupe (at Sainte-Anne town). These were confirmed by a site visit and were added to produce the map of House Sparrow distribution (figure 3).

At Local scale, we have tried to determine the number of birds and nests. At Saint-Martin, we found no nests at GrandCase, Marigot and Mullet Bay villages; in each site we recorded less than 10 birds in the centre of the village. At Cul-de-Sac, there was much bird activity and we noted 50 nests with breeding birds (in new buildings and houses) and two night roosts involving more than 100 birds. There were many feeding sites within and outside the village. We estimated that there were about 200 House Sparrows at this site. So an estimate of at least 230 to 280 House Sparrows could be given for Saint-Martin, with probably several breeding colonies throughout the island. It seems that establishment has succeeded on this island and that propagation (sensus Williamson, 1996) has begun.

On Guadeloupe, about 10 House Sparrows were observed at Sainte-Anne town, but we did not find any nests; so a breeding colony at Sainte-Anne was not confirmed. At Campêche, we found 12 nests with breeding birds. The roost, with a majority of young birds, and the feeding places were located within the village. We estimated that there were at least 40 birds at this site. Thus, the size of the House Sparrow population(s) on Guadeloupe could be about 60 to 80 birds. We can conclude that the House Sparrow has just begun its establishment on this island and constitutes only one population.

\subsection{Source of invaders}

It is impossible to determine the origin of Lesser Antillean House Sparrow populations without a complete genetic analysis of birds from all surrounding regions. Indeed several means of bird transfer are known and could involve several origins. The introduction could be linked to:

(1) Natural movements between neighbouring islands-but the islands in question are very distant from the Greater Antilles where this bird is now settled. However we cannot exclude a scenario of birds 'hopping' from one island to another without becoming established on intermediate islands.

(2) Deliberate human introduction-but this species is not a very attractive bird; it is not a cage-bird. However, some people have reported their wish to introduce this bird on Saint-Martin (Stevenson, 2002, personal communication). In this case the birds could have come from anywhere.

(3) Drift by hurricanes that could move some birds from island to another. Although House Sparrows were first noted just after hurricane Hugo at Sainte Croix (Hayes, 


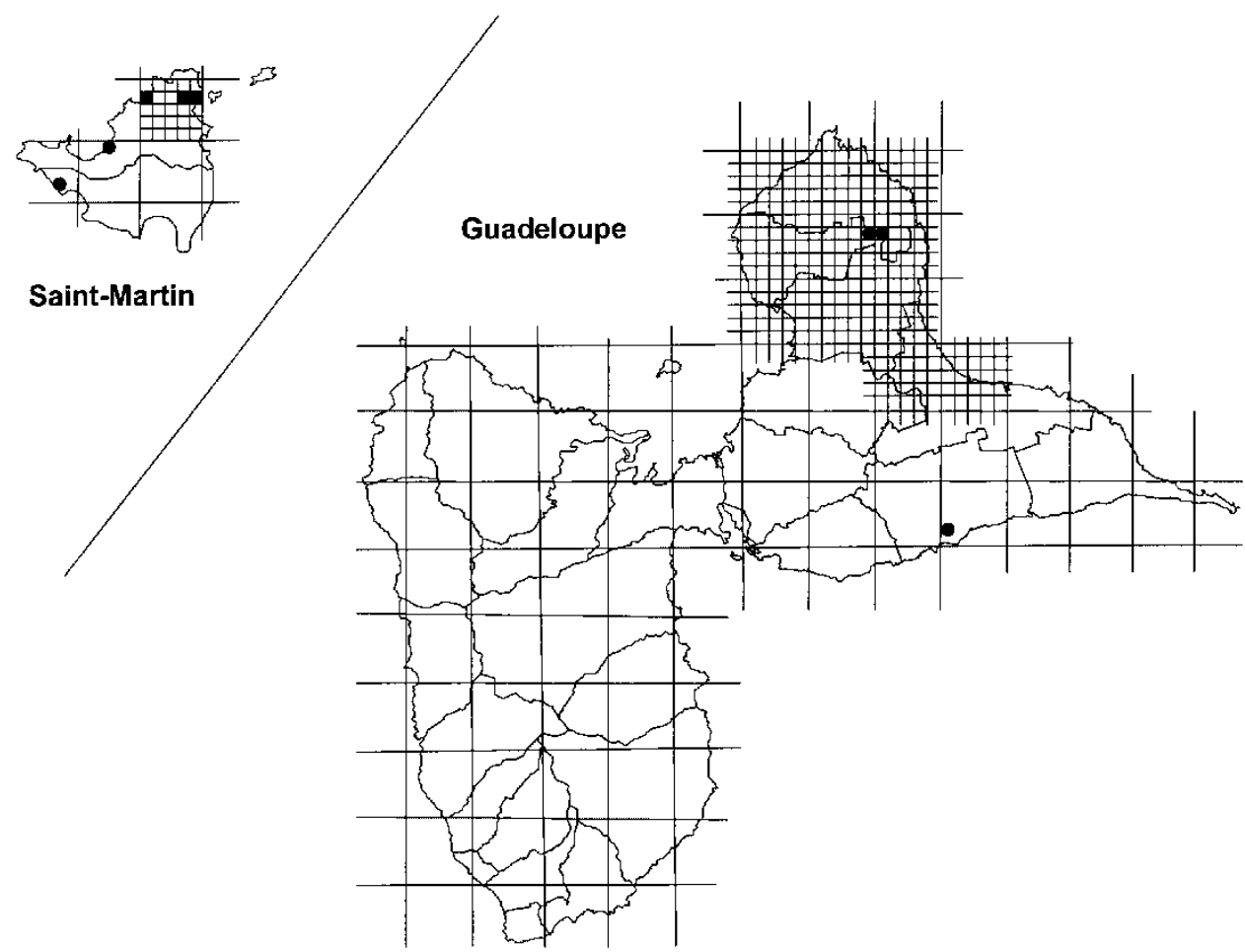

Figure 3. Maps of Saint-Martin (including the Dutch part) and Guadeloupe with census grids and effective House Sparrow observations (black points).

2002, personal communication), this process seems doubtful for Guadeloupe that is located well to the south of the already colonized islands, whereas hurricanes move generally from South-East to North-West.

(4) Transport by ship between islands or between the USA and the West Indies. Both cereal transporters and cruise liners can provide sufficient feeding for several days and so allow survival from existing sparrow sources. A House Sparrow is easily able to travel with the help of feeders on cruise ships (Keith, 2002, personal communication). This appears to be a likely origin of introduction for this bird.

\subsection{Actors involved}

The aforementioned biological-data assessment was conducted by naturalists and scientists at three scales. These different scales corresponded to different levels of ecological organization. The same sharing between several levels is needed in collective decision-making by other actors (figure $1 \mathrm{~A}$ ).

For the House Sparrow problem, each administrative or human competence level could be defined at locality level, island level (or French West Indian level) and Lesser Antilles level (or at a wider scale!) (figure 1B). The experts are previously described and range from local naturalists to international scientists, including regional associations such as the 'Society for the Conservation and Studies of Caribbean Birds' (SCSCB) based on Jamaica. Affected human populations do not exist in the case of the precautionary process. At island level (or French West Indian level), the 'Direction Régionale de l'Environnement' of Guadeloupe (DIREN) represents the local government authority and the 'Office National de la Chasse et de la Faune Sauvage'
(ONCFS) is one of the central government executive organizations. It is clear that effective and sustainable management requires a supplementary level at the Lesser Antillean or West Indian scale (for management decisions and operations at the archipelago level), by local and central government authorities and organizations (figure 1B). This regional level seemed to be lacking up to now and was not considered during this decisionmaking process. The recent 'Centre d'Activité Régionale pour la Caraïbe' (UNEP of United Nations Organization) based on Guadeloupe could be such an organization (Anselme, 2003, personal communication).

\subsection{Steps in decision-making}

During the workshop, the experts presented preliminary results to DIREN and ONCFS in three steps:

(1) Presentation of the House Sparrow species and potential risks. We explained the main patterns of the biology of the House Sparrow (reproductive rate, habitat, diet, etc.) and its capacity to become a successful colonizer in many temperate, tropical and subtropical habitats where it has been deliberately or accidentally introduced. We underlined its impacts on agriculture (crops, fruit, flowers, etc.), on cattle feed lots, harmful effects on the urban environment, and on other species (competition for nest cavities and food). Although only a few publications have referred to competition with small woodpeckers, swallows or small granivorous birds (Petzold, 1979, Bennett, 1990), this last point appeared important for the DIREN that wanted to follow IUCN guidelines (2000) in the prevention of biodiversity loss. 
(2) A description of the House Sparrow's distribution range in the West Indies. Although the bird distribution data can be considered incomplete, we presented maps (figures 2 and 3) to explain both the state of the propagation of the bird through the West Indies, and the possible role and international responsibility of Guadeloupe if this island became a source of House Sparrow dispersion for other Lesser Antillean islands.

(3) Suggestion of possible management strategies: (i) no action on House Sparrow populations, data on effective damage being unavailable; (ii) a rapid attempt to eradicate birds to suppress all future problems, with monitoring to avoid a reinvasion; (iii) some population reductions to limit the invasion. To help in the decisionmaking we presented various methods for catching and killing the birds (traps, nets, shooting, etc.) and the difficulty of directly destroying House Sparrow nests because of their very high locations on houses or electricity poles. Whatever that the authorities choose, we also underlined the need to put into place a program of monitoring House Sparrow dispersion.

The result of the collective negotiation was first to decide to build a House Sparrow monitoring network throughout the French West Indies (conducted both ONCFS officers and ornithological associations) and, second, to eradicate this bird on Guadeloupe where it has just become established (less than 100 birds in only one or two colonies), but not to act on SaintMartin where the House Sparrow was more settled in several colonies. This difference in decision was also supported by several factors such as the facts that Saint-Martin has little agricultural activity, has urban House Sparrow populations, is closer to House Sparrow sources and is a major cruise liner centre.

\section{Conclusions}

The House Sparrow seems to be continuing its propagation through the West Indies. The establishment of House Sparrow in West Indian islands is more likely to have adverse effects than present any advantage. So, following a precautionary principle, both in terms of biodiversity conservation and the protection of human activities, a decision was quickly made on whether to support the choice of eradication of this alien bird, or not. The decision-making was based on a collective negotiation. To make this strategy more effective, we have recommended applying multiple-scale methodology to the ecological assessment, to the actor system and to the awareness or the action programs. The more integrative levels have to be involved to make the management sustainable.

For example, the West Indies was an obvious regional level of ecological organization for studying House Sparrow distribution. Actors also have to be considered at this same level. In our collective decision-making, government authorities and government executive organizations were lacking at this regional level. The sustainability of French West Indies decisions is dependent on relationships at a much wider geographical scale.

In the same way, awareness programs have to be set up on as many islands as possible to avoid new introductions by local people and tourists. Communications with shipping companies and tour operators could be a basis for a precautionary program in the West Indies if we assume that House Sparrow could have been transported by ship. However, recent observations in 2003 of small groups of House Sparrows on Désirade and Petite Terre islands (small islands within $10 \mathrm{~km}$ from Guadeloupe) have shown that the hypothesis of 'island-hopping' by birds cannot be discounted and support the urgency of management decision.

We agree with recommendations for better communications between scientists and managers (Bouffard and Hanson, 1997) and to clearly involve stakeholders in the decision-making process (Deker and Chase, 1997, Norton et al., 1999); we can add that it is essential for better rapid decision-making. The procedure involving both multi-spatial scale assessment and multi-actor workshop needs to be refined but its prospects are promising. This procedure is currently being tested for another bird, Pycnonotus jocosus, recently introduced on Reunion Island and for an amphibian, Rana catesbeiana, recently introduced in south-west France.

\section{Acknowledgments}

This study was funded by the 'Direction Régionale de l'Environnement' of Guadeloupe. We are grateful to Marie-Eve Jaffard (AMAZONA association) for assistance in fieldwork, to André Lartiges (Office National de la Chasse et de la Faune Sauvage) for assistance in spatial methodology and to Bob Britton who improved the English.

\section{References}

AOU, 1998. The A.O.U. Check-List of North American Birds, 7th edn (Washington, DC: The American Ornithologists' Union).

BENNET, W. A., 1990. Scale of investigation and the detection of competition: an example from the House Sparrow and House Finch introductions in North America. The American Naturalist, 135, 725-747.

BOUFFARD, S. H. and HANSON, M. A., 1997. Fish in waterfowl marshes: waterfowl managers' perspective. Wildlife Society Bulletin, 25, 146-157.

BRYANT, P. J., 2002. Exotic Introductions. Chapter 9, in Biodiversity and Conservation, a hypertext book. http://darwin.bio.uci.edu/ sustain/bio65/ lec09/b65lec09.htm

CLERGEAU, P., 1995. Importance of multiple scale analysis for understanding distribution and for management of an agricultural bird pest. Landscape and Urban Planning, 31, 281-289.

CLERGEAU, P., 1997. Oiseaux à risques en ville et en campagne, vers une gestion intégrée des populations (Paris: INRA ed.).

CLERGEAU, P. and MANDON-DALGER, I., 2001. Fast colonization of introduced bird: the case of Pycnonotus jocosus on Mascarene Islands. Biotropica, 33, 542-546.

ClergeAU, P., MANDON-DAlger, I. and GEORGER, S., 2002. Mise en place d'une gestion intégrée d'un oiseau ravageur des cultures à la Réunion. Ingénieries, 30, 71-80.

CHASE, L. C., SIEMER, W. F. and DECKER, J., 2002. Designing stakeholder involvement strategies to resolve wildlife management controversies. Wildlife Society Bulletin, 30, 937-950.

CONOVER, M. R., 1997. Wildlife management by metropolitan residents in the United States: practices, perceptions costs, and values. Wildlife Society Bulletin, 25, 306-311.

DAWSON, D. G., 1970. Estimation of grain loss due to Sparrows Passer domesticus in New Zealand. New Zealand Journal of Agricultural Resources, 13, 681-688.

DEKER, D. J. and CHASE, L. C., 1997. Human dimension of living with wildlife: management challenges for the 21 st century. Wildlife Society Bulletin, 25, $788-795$. 
FEARE, C. J., 1991. Control of bird pest populations. In C. M. Perrins, J. D. Lebreton, and G. J. M. Hirons (eds) Bird population studies, relevance to conservation and management (Oxford: Oxford University Press), pp. $463-478$.

FLEISCHER, R. C., 1982. Clutch size in Costa Rican House Sparrows. Journal of Field Ornithology, 53, 3.

GHABBOUR, S. I., 1972. Birds as agricultural pests in Africa. Cairo African Studies, 1, 101-123.

GODARD, O., 1997. Le principe de précaution (Paris: INRA - Maison des Sciences de l'Homme ed.).

IUCN, 2000. IUCN guidelines for the prevention of biodiversity loss due to biological invasion (Gland: IUCN).

JOHNSTON, R. F. and GARRET K. L., 1994. Population trends of introduced birds in western North America. In J. R. Jehl and N. K. Johnson (eds) $A$ century of avifaunal change in western North America, Studies in Avian Biology 15 (CA: C.O.S.), pp 221-231.

KERN, W. H., 2003. House or English Sparrow. Institute of Food and Agricultural Sciences, University of Florida. http://edis.ifas.ufl.edu/UW119

LE LAY, G., CLERGEAU, P. and HUBERT-MOY, L., 2001. Computerised map of risk to manage wildlife species in urban areas. Environmental Management, 27, 451-461.

LEVESQUE, A., 1999. Oiseaux: observations remarquables en 1999. Le Toto bois, 6,6 .

LEVESQUE, A., 2001. Kronik Ornitho. Le Toto-Bois, 9, 4.

LEVESQUE, A. and CLERGEAU, P., 2002. First colonization of the Lesser Antilles by the House Sparrow Passer domesticus. El Pitirre, 15, 73-74.

MACK, R. N., SIMBERLOFF, D., LONSDALE, W. M., EVANS, H., CLOUT, M. and BAZZAZ F., 2000. Biotic invasions: causes, epidemiology, global consequences and control. Issues in Ecology, $\mathbf{5}$.

MONACHESI, A. and ALBALADEJO, C., 1997. La gestion concertée de l'eau dans un basin versant pampéen. Apprendre l'hydrolique et la démocratie. Natures Sciences Sociétés, 5, 24-38.

NORTON, G. A., ADAMSON, D., AITKEN, L. G., BILSTON, L. J., FOSTER, J., FRANK, B. and HARPER, J. K., 1999. Facilitating IPM: The role of participatory workshops. International Journal of Pest Management, 45, $85-90$.
O'RIORDAN, T. and CAMERON, J., 1994. Interpreting the precautionary principle (London: Earthscan ed.).

PETZOLD, H. G., 1979. Haussperling (Passer domesticus) nistet auf Kuba in spechthöhlen. Beitr. Vogelkd., 23, 333-334.

PINOWSKI, J. and SUMMERS-SMITH, J. D., 1990. Granivorous birds in the agricultural landscape. Proceedings of General Meetings of the Working Group on Granivorous Birds, INTECOL, Canada, June 1986.

RAFFAELE, H., WILEY, J., GARRINO, O., KEITH, A. and RAFFAELE, J., 1998. A guide to the birds of the West Indies (C. Helm ed., London: A \& C Black).

REITER, K. D., BRUNST, M. W. and SCHMIDT, R. H., 1999. Public attitudes toward wildlife damage management and policy. Wildlife Society Bulletin, 27, $746-758$.

REKASI, J., 1976. The diet of the House Sparrow Passer domesticus in its great feeding concentration places in Hungary. International Studies on Sparrows, 9, 72-82.

RIDGELY, R. S. and GREENFIELD, P. J., 2001. The bird of Ecuador (New York: Cornell University Press).

ROGERS, M. F., SINDENT, J. A. and DE LACY, T., 1997. The precautionary principle for environmental management: a defensive-expenditure application. Journal of Environmental Management, 51, 343-360.

ROYALL, W. C., 1969. Trapping House Sparrows to protect experimental grain crops. US Dep. of the Interior Fish and Wildlife Service, Wildlife Leaflet, 484, $1-4$.

SIBLEY, D. A., 2000. The Sibley Guide to Birds (New York: Alfred A. Knopf ed.). SOULE, M. E., 1990. The onslaught of alien species and other challenges in the coming decades. Conservation Biology, 4, 233-239.

SUMMERS-SMITH, J. D., 1988. The Sparrows (Poyser, Calton).

WILEY, J. W., 2000. A bibliography of ornithology in the West Indies. Proceedings of the Western Foundation of vertebrate Zoology (California), 7, 1-187.

WILLIAMSON, M., 1996. Biological invasions (London: Chapman and Hall). 